\title{
58. REPROCESSED WELL LOGS FROM HOLE 747C USED IN LOCAL AND REGIONAL CORRELATION1
}

\author{
Elizabeth Lewis Pratson, ${ }^{2}$ Roger N. Anderson, ${ }^{2}$ and Jennifer Tivy ${ }^{2}$
}

\begin{abstract}
A single seismic stratigraphic logging string, which comprised the natural gamma-ray, phasor induction, and array sonic tools, recorded log data at Hole $747 \mathrm{C}$. The data has been reprocessed at shore-based computing centers and the results are presented in this study. The reprocessed logs were used for several purposes. A lithologic column was calculated at Hole $747 \mathrm{C}$ from natural gamma-ray and resistivity logs. A carbonate curve derived from the column was used for local correlation between holes at Site 747. The Th/U ratio was used to detect ash layers and so to provide regional correlation between Site 738 of Leg 119, Sites 747 and 750 of Leg 120, and Site 752 of Leg 121. The ash layer frequency was used to infer activity in the Kerguelen hotspot.
\end{abstract}

\section{INTRODUCTION}

Leg 120 can be combined with Legs 119 and 121 as part of a generally north-south transectional study across the eastern Indian Ocean from Broken Ridge, through the Kerguelen Plateau, to Prydz Bay, Antarctica (Fig. 1). One of the main goals of these legs was to understand the paleoceanographic history of this portion of the Indian Ocean and so to resolve the debated tectonic evolution of the Kerguelen Plateau (Munschy and Schlich, 1987). This study will concentrate on the results from Site 747 of Leg 120 , located in the transitional zone between the northern Kerguelen-Heard Plateau and the Southern Kerguelen Plateau. The main objective of work at this site was to determine the nature and age of the basalts in this portion of the plateau. This study will also concentrate on overlying sediments at this site, as they were also considered central to understanding the subsequent tectonic history of the area (Shipboard Scientific Party, 1989).

The study will (1) discuss the corrections applied to the logs and present the results of the reprocessed well logs from Hole $747 \mathrm{C}$; (2) use a matrix inversion program to calculate from the well logs the lithology at Hole 747C; (3) use a curve from the calculated lithology to compare Hole $747 \mathrm{C}$ to core data from Hole $747 \mathrm{~A}$; (4) use the $\mathrm{Th} / \mathrm{U}$ ratio to detect ash layers and to attempt regional correlations among Sites 738, 747,750 , and 752 of Legs 119,120 , and 121; and (5) discuss how the Th/U ratio may be used to make inferences regarding hotspot activity by using the periodicity of the occurrences of ash layers as an indication of volcanic frequency.

\section{DATA ACQUISITION}

Holes $747 \mathrm{~A}, 747 \mathrm{~B}$, and $747 \mathrm{C}$ were drilled by combining advanced piston corer (APC), extended core barrel (XCB), and rotary core barrel (RCB) techniques. Hole 747A was cored to $256 \mathrm{~m}$ below sea floor (mbsf), at which depth it was decided to abandon the hole because chert layers wore the teeth off the XCB. Hole 747B was cored to $50.3 \mathrm{mbsf}$ to complete coring objectives in the upper section of the Site. Hole $747 \mathrm{C}$ was washed from the mud line to $159 \mathrm{mbsf}$ and then

\footnotetext{
${ }^{1}$ Wise, S. W., Jr., Schlich, R., et al., 1992. Proc. ODP, Sci, Results, 120: College Station, TX (Ocean Drilling Program).

${ }^{2}$ Lamont-Doherty Geological Observatory, Columbia University, Palisades, NY 10964, U.S.A.
}

cored from 159 to 206.5 mbsf to recover the lower Maestrichtian sediments. Recovery in this section was poor (roughly $39 \%$ ). The hole was then washed to 252 mbsf and continuously cored through Cretaceous chalk and chert to $295.1 \mathrm{mbsf}$ with very poor core recovery $(13.1 \%)$. In preparation for further drilling, the hole was conditioned to remove accumulated rubble at the bottom of the well. The next core encountered basalt after only an additional $1.5 \mathrm{~m}$ of penetration. The sediment-basement contact was not recovered in the cores. The remainder of the basalt section was then cored to a total depth of 350.5 mbsf with $37.8 \%$ recovery.

In view of the sporadic coring and poor recovery, logging was very important at Hole $747 \mathrm{C}$ because it could fill the gaps where no core data existed. Even though three logging runs had been planned for this last hole of Site 747 , only one logging run was completed due to significantly deteriorating weather conditions. The logging tool string consisted of the Schlumberger phasor induction/resistivity, array sonic, natural gamma-ray, and caliper tools. A brief explanation of these tools can be found in the "Explanatory Notes" chapter of the Initial Reports volume for Leg 120 (Schlich, Wise, et al., 1989). The logs recorded by the natural gamma-ray and phasor induction tool were of good quality, but the sonic logs were significantly affected by the heavy seas, which induced noise into the signal.

\section{WELL LOG DATA REDUCTION}

The data recorded from these Schlumberger tools are transmitted digitally up a wireline to be recorded and processed on the ship in a Schlumberger Computer Service Unit (CSU). The results from the CSU are made available as "field logs" for initial interpretation while still out at sea. These field logs are later reprocessed to correct for logging speed changes and borehole conditions. This reprocessing improves the accuracy of the logs and enhances their usefulness for geologic interpretation. The logs reprocessed were the natural gamma-ray and phasor induction.

\section{Natural Gamma-Ray Logs}

The natural gamma-ray tool (NGT) measures the total natural gamma radiation of the formation and provides a spectral analysis of the gamma-ray energies as they are captured by a sodium iodide scintillator counter (Serra, 1984). Analysis of the spectra yields the absolute abundances of the three contributing elements: thorium, uranium, and potas- 


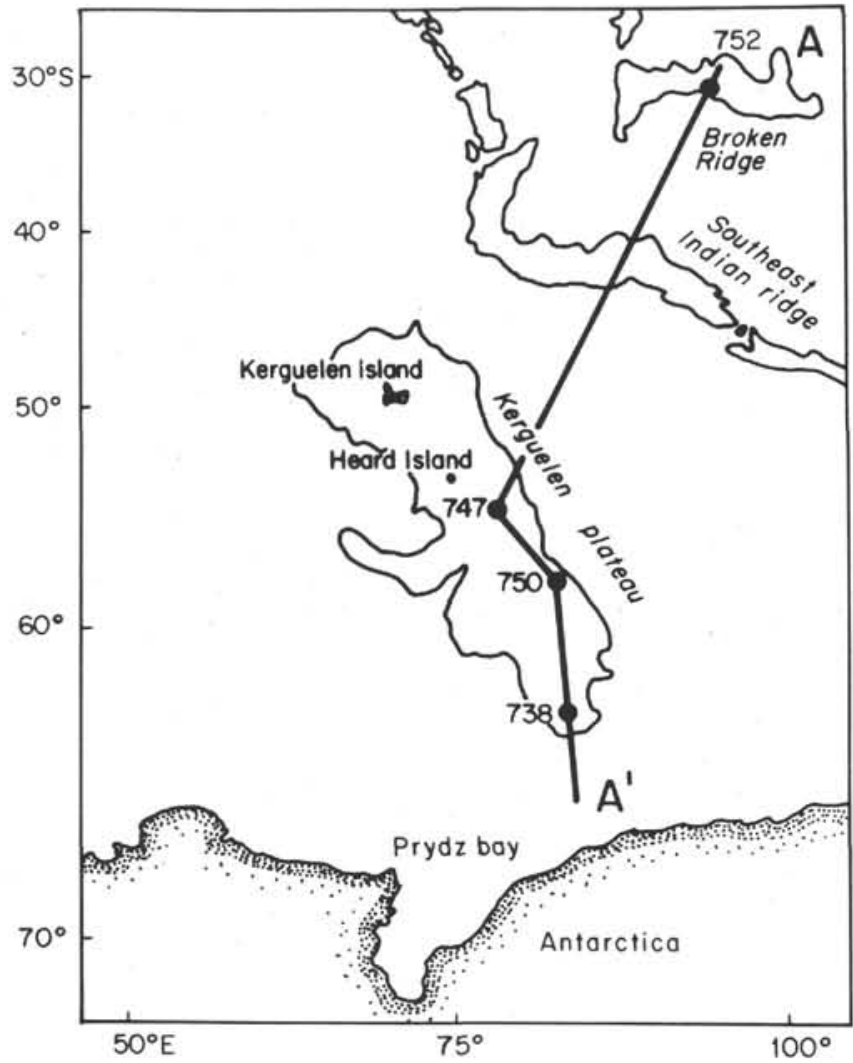

Figure 1. Location of study area showing Site 738 from Leg 119, Sites 747 and 750 from Leg 120, and Site 752 from Leg 121.

sium. Although this analysis is initially done at sea, the calculation is routinely redone on shore to correct for the effects of drilling fluid, and for variations in logging speed and borehole size. Because statistical errors in the logs often create erroneously negative readings and anti-correlations, a Kalman-type filter is applied on the CSU at sea to reduce these effects. Recent findings, however, indicate that an Alpha filter may better eliminate statistical noise (C. Flaum, pers. comm., 1989). We have found that the Alpha filter smooths the data too much when applied as suggested by Schlumberger. Before calculating thorium, uranium, and potassium in this study area, therefore, the logs have been reprocessed using an Alpha filter without the large smoothing window applied to the input count rates.

Figure 2 displays both the field and the reprocessed logs of the natural gamma-ray tool. Note that the field and recomputed total gamma-ray curves (SGR) are similar, whereas the thorium, uranium, and potassium curves show different values. This indicates a miscalibration of the three radioactive components calculated at sea. The solid line in Figure 2 shows the improved calibration of thorium, uranium, and potassium and the decrease in noise after Alpha filtering.

\section{Phasor Induction Logs}

Induction resistivity logs provide measurements of deep, medium, and shallow resistivity. The older induction tools provide only the in-phase ( $\mathrm{R}$ signal) induction measurements, which contain blind frequencies that the tool will not respond to. The newer phasor tool provides not only the in-phase, but also the out-phase $(\mathrm{X})$ quadrature signal. Phasor processing combines both the $\mathrm{X}$ and $\mathrm{R}$ signals to fill in the blind frequencies, providing enhanced resolution of the tool and more accurate resistivity readings. This technique has been found to increase the vertical resolution of the tool from 2 to $1 \mathrm{~m}$ (7-3 ft) (Allen et al., 1988). The induction curves have been processed by the Schlumberger Field Log Interpretation Center in New Orleans.

Enhanced resolution processing produced curves that were similar to the field resistivity curves in the sediment section of the well because the sediment had such uniformly low resistivity values. The enhancement processing did, however, improve resolution in the basement section of the well, and a number of thin basalt flows have been interpreted. Figure 3 compares the field resistivity logs with the logs that have been reprocessed using enhanced resolution in the basement. The reprocessed logs distinguish the individual basalt layers much more clearly.

\section{TRANSFORMATION OF WELL LOGS INTO LITHOLOGY LOGS}

The lack of core in Hole $747 \mathrm{C}$ impedes comparison or correlation with other holes drilled at this site. Therefore, a lithology reconstruction from well logs at Hole $747 \mathrm{C}$ is useful for making comparisons with adjacent holes where more core data exists. Velocity, resistivity, and gamma-ray logs provide measurements with which to distinguish the major lithologic types. These logs can be transformed into lithology logs using a matrix inversion process (Doveton, 1986). ELAN (for elemental analysis), written by Schlumberger, is a matrix-inversion-based program which provides an optimized linear solution to transform geochemical or geophysical measurements from well logs into mineralogical percentages.

The lithologic types solved for are determined primarily by core descriptions and then by the character of logs. The number of lithologies solved for is limited by the number of tools run. Since only one logging run was completed at the site, only the major lithologic groups could be considered. The five lithologies resolved were: calcareous oozes and chalks, volcaniclastic sands and clays, volcanic ash layers, fresh basalts, and altered basalts or clays. To accomplish even these five solutions, the well was broken up into an upper sediment section, involving three lithologies, and a lower basement section, involving two lithologies. The logging curves found most useful in the matrix inversion processing of the lithologies at this site were the total gamma ray (SGR), the ratio of thorium and uranium (Th/U) from the natural gamma-ray tool, and the medium-induction resistivity (ILM). The sonic log was not used in the inversion process because of the noise induced by the poor weather conditions encountered during the logging run.

The well logs can be related to the percentage of each lithologic type by a linear response equation such as:

$$
L=X \cdot P,
$$

where $L=$ the corrected tool readings (SGR, Th/U, ILM), $P=$ percentages of lithologic type, and $X=\log$ response value for each lithologic type.

A matrix of coefficients $(X)$ is built from log responses, which are derived by creating an hypothetical pure lithology for each of the dominant lithologies. The unknown percentage $(P)$ is resolved by inverting the matrix $X$ to yield the following equation:

$$
P=X^{-1} \cdot L
$$

The equation is applied at each depth interval $(0.1524 \mathrm{~m})$, giving a continuous dry weight percentage of the different lithologies with depth in the well. 


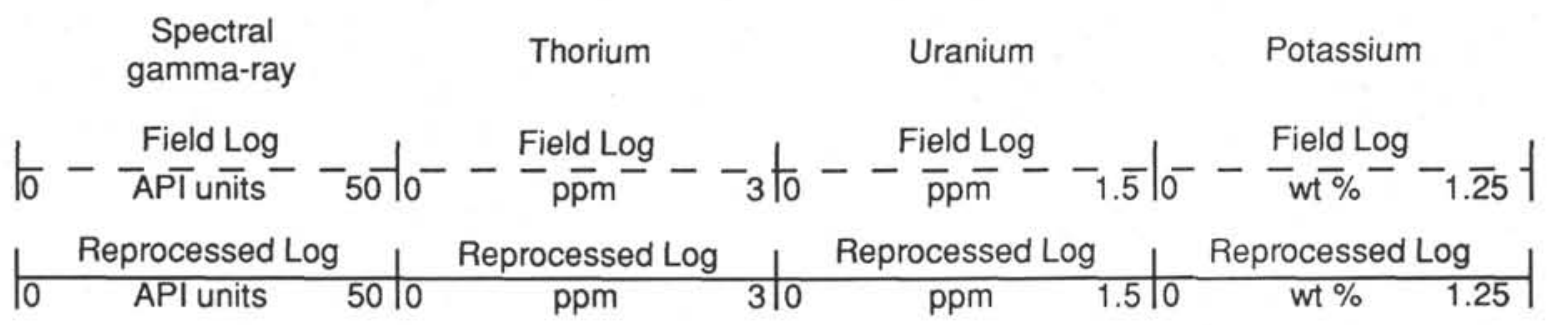

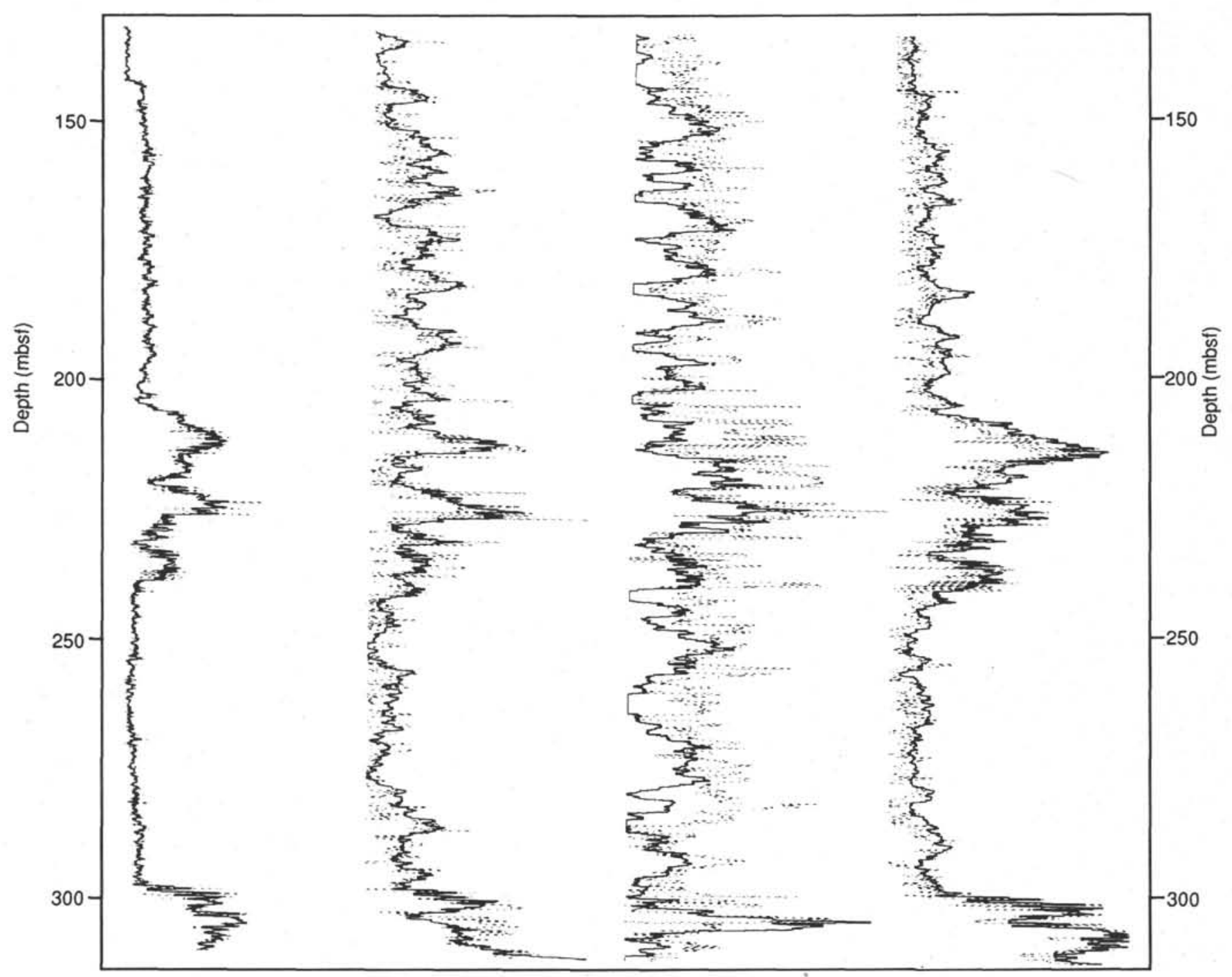

Figure 2. Natural gamma-ray log from Hole 747C. Field logs (dashed) are much noisier and contain erroneous negative values compared with the reprocessed logs (solid).

\section{Basement Interpretation}

The basement lithology recovered from Hole $747 \mathrm{C}$ is of two basic types: basalts containing only minor alteration and basalts that are brecciated and highly altered. The fairly fresh basalts are aphyric to sparsely phyric containing vesicles that are filled in by secondary minerals of zeolites, clay, and minor calcite. The brecciated basalts consist of highly altered, microcrystalline, vesicular basalts, which are cemented with clays. The alteration minerals comprise clays, zeolites, prehnite, goethite, calcite, and quartz (Shipboard Scientific Party, 1989).

The logs of the basement section can be used to distinguish between the two lithologic types as they are found in the formation. Fresh basalts have very high resistivity values and slightly lower natural gamma-ray contents. The altered basalts have $\log$ resistivity values that are much lower, falling in the range expected of clays. Table 1 summarizes the matrix of response values used to solve for the lithology in the basement section of the well. Response values in the basement section of the well were estimated based on the responses in this well and those of previous ODP wells (Pezard, 1990; Broglia and Moos, 1988).

Figure 4 shows the estimated percentages of fresh and altered basalts predicted by the logs. Two distinct units of fresh basalt are separated by fairly thick units of altered basalt. Distinction of the individual flow units is better seen on 


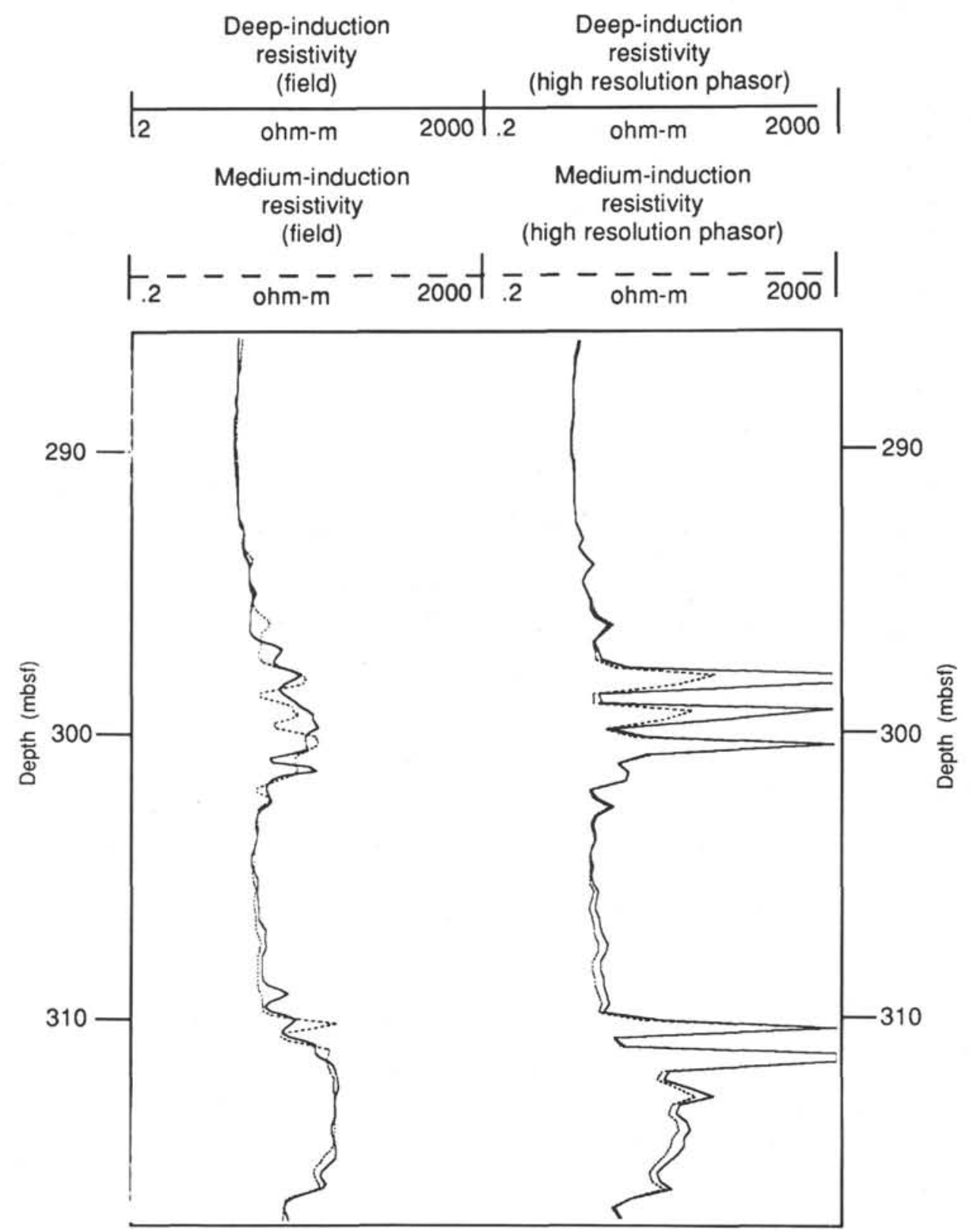

Figure 3. Field resistivity curves (left) and enhanced resolution phasor curves (right). The latter curves show a significant improvement in terms of flow-boundary differentiation.

the enlarged section of the high resolution resistivity curve (Fig. 3). At least three basalt flows have been interpreted in the upper basalt unit and possibly five in the lower basalt unit.

\section{Sediment Interpretation}

Sediment recovered from Site 747 consists of pelagic carbonate ooze and chalk. Diatomaceous ooze and vitric ash

Table 1. Log response values used for lithologic interpretation in the basalt section.

\begin{tabular}{lcc}
\hline \multicolumn{1}{c}{ Lithology } & SGR & ILM \\
\hline Fresh basalt & 18 & 30 \\
Altered basalt & 27 & 2 \\
\hline
\end{tabular}

are observed in the upper cores, volcaniclastic sands to pebbles in the middle, and black chert in the lower cores (Shipboard Scientific Party, 1989). Volcanic ash is seen as a minor component in the upper portion of Hole 747A. Descriptions of the ash layers range from dark specks to silt- and sand-size vitric shards. No ash was recovered from Hole 747C because this section of the well was washed through instead of being cored. Multicolored volcaniclastics and polygenetic sands are observed in Hole 747A as a very thin, $40-\mathrm{cm}$-thick unit. A similar lithology of cobble-size conglomerates is seen in Hole $747 \mathrm{C}$. Clasts are of polygenetic origin-they are seen in core as smectitic clays, devitrified volcanics, chert, and limestones. The lower section of both holes encountered authigenic, vitreous to cloudy chert.

The logs distinguish three sediment types: carbonate oozes and chalks, volcaniclastics, and volcanic ash layers. (The 


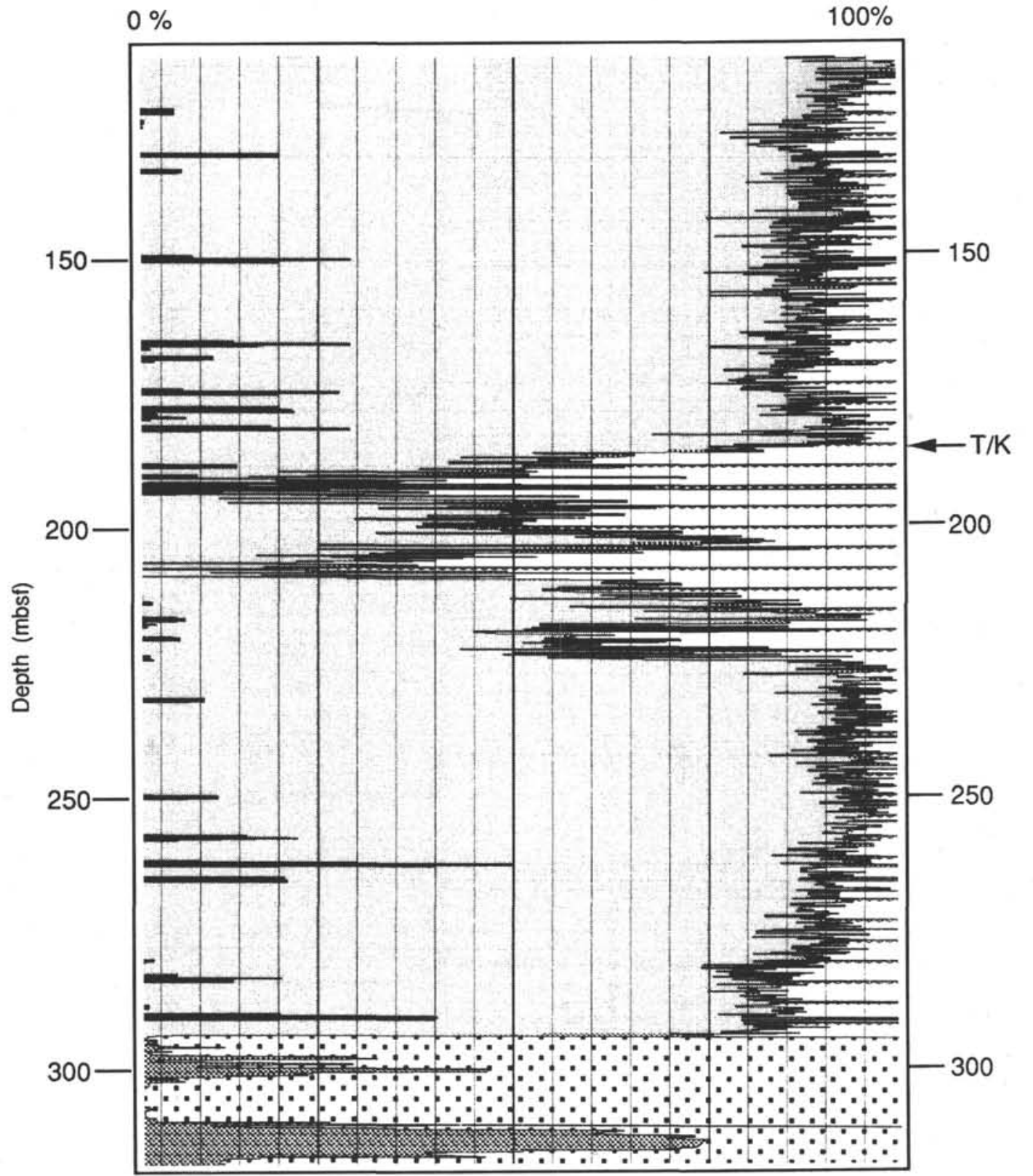

Carbonates

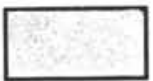

Volcaniclastics

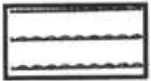

Volcanic Ash

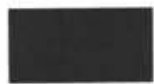

Fresh Basalt

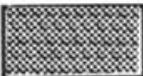

Altered Basalt

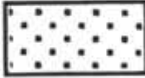

Figure 4. Lithologic abundances from Hole $747 \mathrm{C}$ based on log response values.

diatomaceous ooze and the chert seen in the cores were not identifiable on the logs used in Hole $747 \mathrm{C}$ and therefore were not distinguished in this study.) The three sediment lithologies are distinguished using the total gamma ray, the ratio of thorium to uranium, and the medium resistivity logs. In this study the pelagic oozes and chalks are grouped into one lithologic group called "carbonates," because the logs yield similar low resistivity and total gamma-ray values. Reworked sand- to cobble-size gravel seen in core is labeled "volcaniclastic,"' because it has similar high total gamma-ray readings. The third group, called "ash layers" in this study, has a consistently high $\mathrm{Th} / \mathrm{U}$ ratio.

Table 2 summarizes the parameters used in transforming the well logs into lithologic logs in the sediment section of the well. The average total gamma-ray response values for calcite and silicate minerals and for clays, which were used for the matrix inversion computation, can be found in the literature
(Edmunson and Raymer, 1979; Serra, 1984). Response values for the carbonate ooze and chalk sediments reflect those found in the literature for carbonates. Because the volcaniclastic sediments are not made up of just a single mineral type, the log response values were derived from estimations based on a combination of values for clays, sands, and feldspar. Response values of $\mathrm{Th} / \mathrm{U}$ were estimated based on the chart seen in Figure 5. Thorium is normally very high in unaltered

Table 2. Log response values used for lithologic interpretation in sediments.

\begin{tabular}{lrrr}
\hline \multicolumn{1}{c}{ Lithology } & SGR & Th/U & ILM \\
\hline Carbonates & 2 & 1 & 1.5 \\
Volcaniclastics & 30 & 2 & 4.0 \\
Volcanic ash & 6 & 10 & 1.5 \\
\hline
\end{tabular}




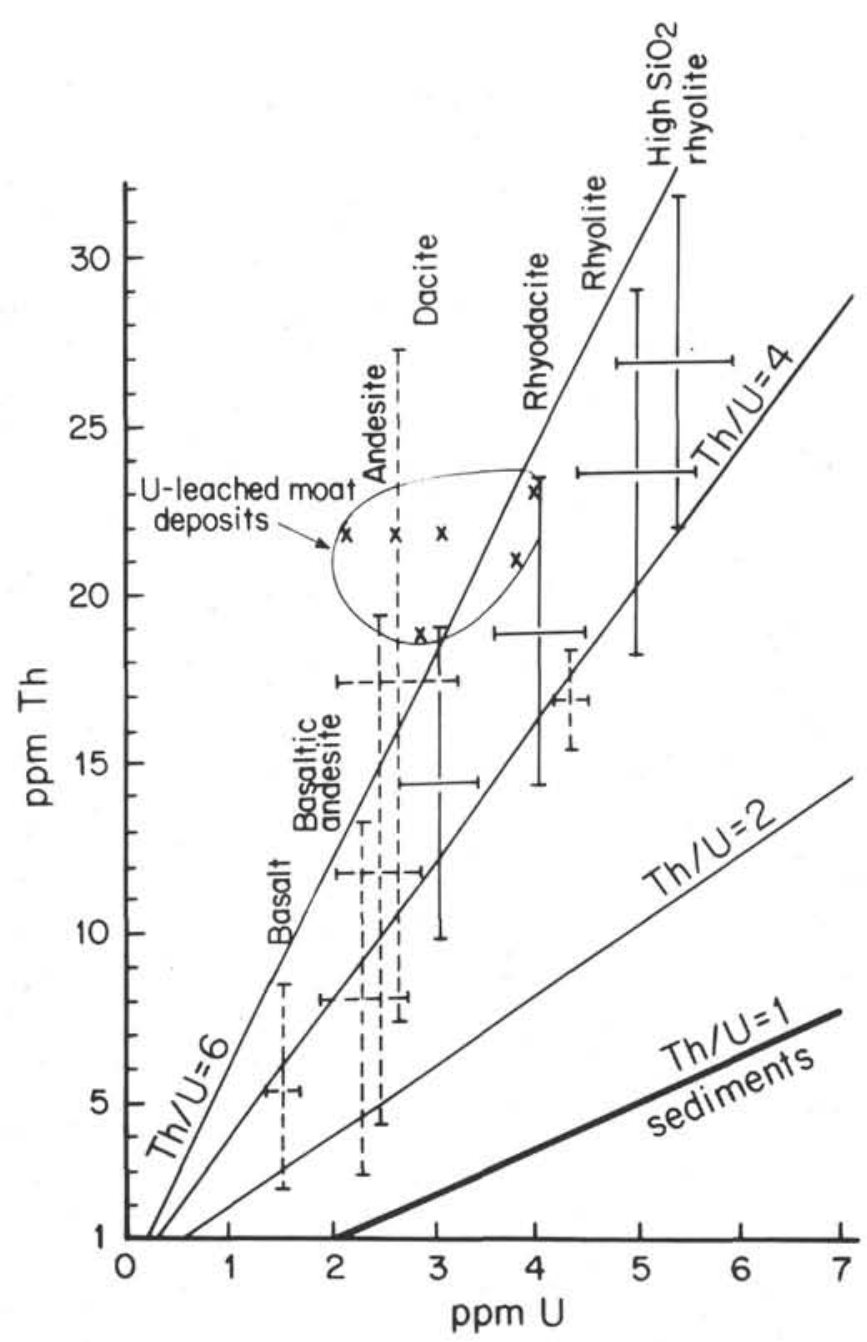

Figure 5. Relationship between thorium and uranium in igneous and sedimentary rocks (Serra, 1986). The $\mathrm{Th} / \mathrm{U}$ ratio of basalts, andesites, and high silica rhyolites averages $4: 1$; that of pelagic sediments is $<1: 1$. The small letter " $x$ " shows that even leached volcanic ashes from the moats of volcanic islands like Hawaii maintain this high $\mathrm{Th} / \mathrm{U}$ ratio.

volcanic rocks, whereas uranium (associated with organic material) is normally very low (Serra, 1986). High $\mathrm{Th} / \mathrm{U}$ ratio values, therefore, are thought to indicate volcanic ash in the core.

The chalk and ooze lithology is the dominant sediment type in Hole $747 \mathrm{C}$. This volume of carbonate rock from the transformation of well logs at Hole $747 \mathrm{C}$ can be compared with the percentage $\mathrm{CaCO}_{3}$ determined from core analysis at Hole 747A (Fig. 6). The sediment section was recovered almost in full from Hole 747A, and extensive core measurements of percentage calcium carbonate were taken. These measurements were interpolated, creating a "log" of core data to compare with the derived carbonate curve. The interpolated $\mathrm{CaCO}_{3}$ from the cores at Hole $747 \mathrm{~A}$ and the estimated carbonate from log responses at Hole $747 \mathrm{C}$ overlay well in the upper and lower sections of the hole. A large discrepancy occurs in the middle section of the hole (184-227 mbsf), where volcaniclastic sediments are inferred from the logs at Hole 747C. Volcaniclastics were observed in Hole $747 \mathrm{~A}$ but only as minor components. The transformation of

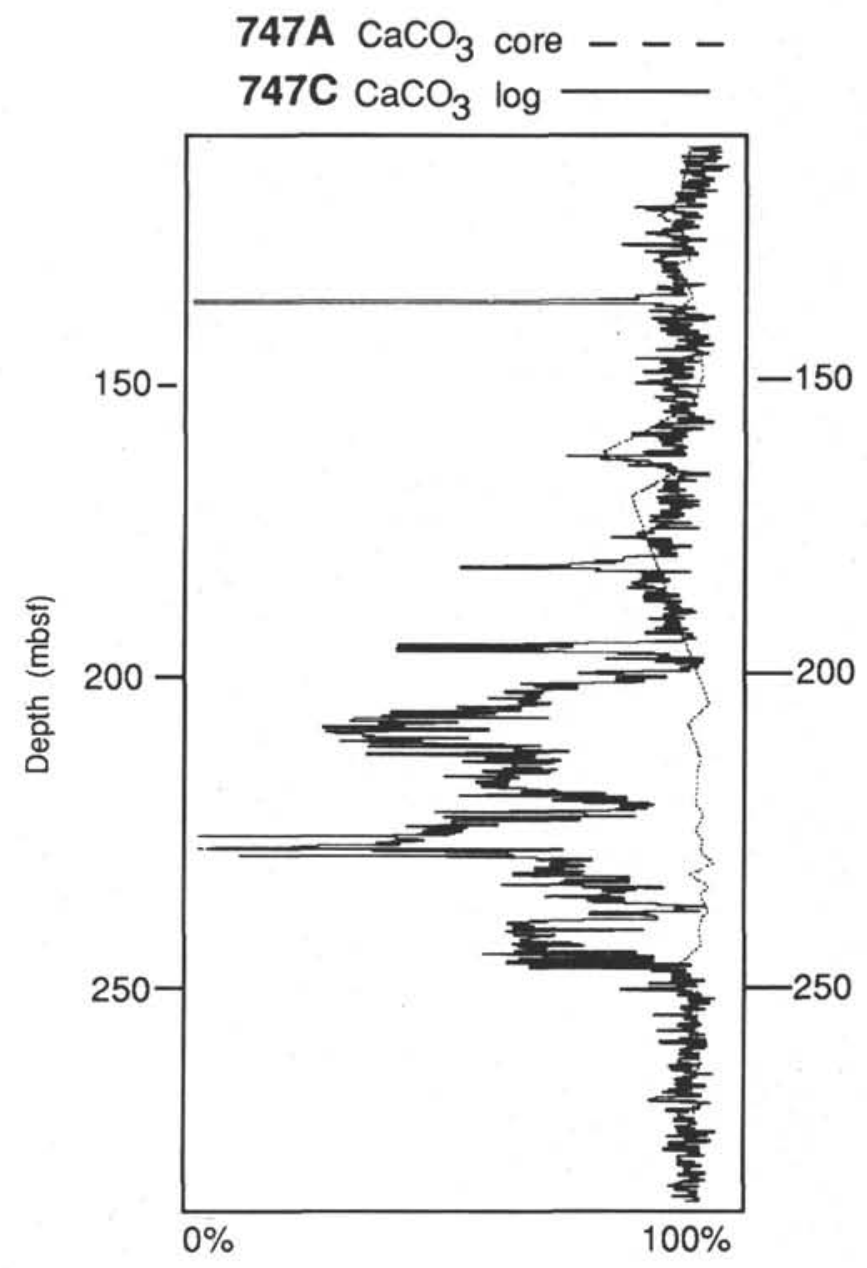

Figure 6. Comparison between carbonate values computed from logs at Hole $747 \mathrm{C}$ (solid line) and interpolated $\mathrm{CaCO}_{3}$ values from Hole 747A core (dashed line). The large difference between 200 and $247 \mathrm{~m}$ on Hole $747 \mathrm{C}$ indicates that this section has been replaced by volcaniclastic material.

well logs into lithology curves enables one to compare Hole $747 \mathrm{C}$, where little core exists, with Hole 747A, where recovery was good.

The second most dominant lithology is volcaniclastics. A quantitative estimate of the percentage of volcaniclastic sediments derived from the inversion process is depicted in Figure 4. A large unit of volcaniclastics occur near the Cretaceous/Tertiary boundary (183 mbsf). This can be broken down into three subunits, each indicating a detrital event. It is speculated that the volcaniclastics were probably deposited as debris flows (Shipboard Scientific Party, 1989), and this study reinforces these conclusions.

Volcanic ash layers make up a minor part of the sediment lithology. Ash layers are marked on the well logs by thin, sharp increases in the $\mathrm{Th} / \mathrm{U}$ ratio. Volcanic ash layers are described in the upper portion of Site 747; however, this portion of the well was not logged. Therefore, ash layers here are described and correlated to logs in adjacent Site 752 of Leg 121 (Peirce et al., 1989). A number of strong peaks occur on the $\mathrm{Th} / \mathrm{U}$ ratio log, causing ash to be interpreted by ELAN throughout Hole $747 \mathrm{C}$. More detailed observations of the core and of magnetic susceptibility measurements from cores at Site 747 will confirm the presence of these ash layers in the formation. 


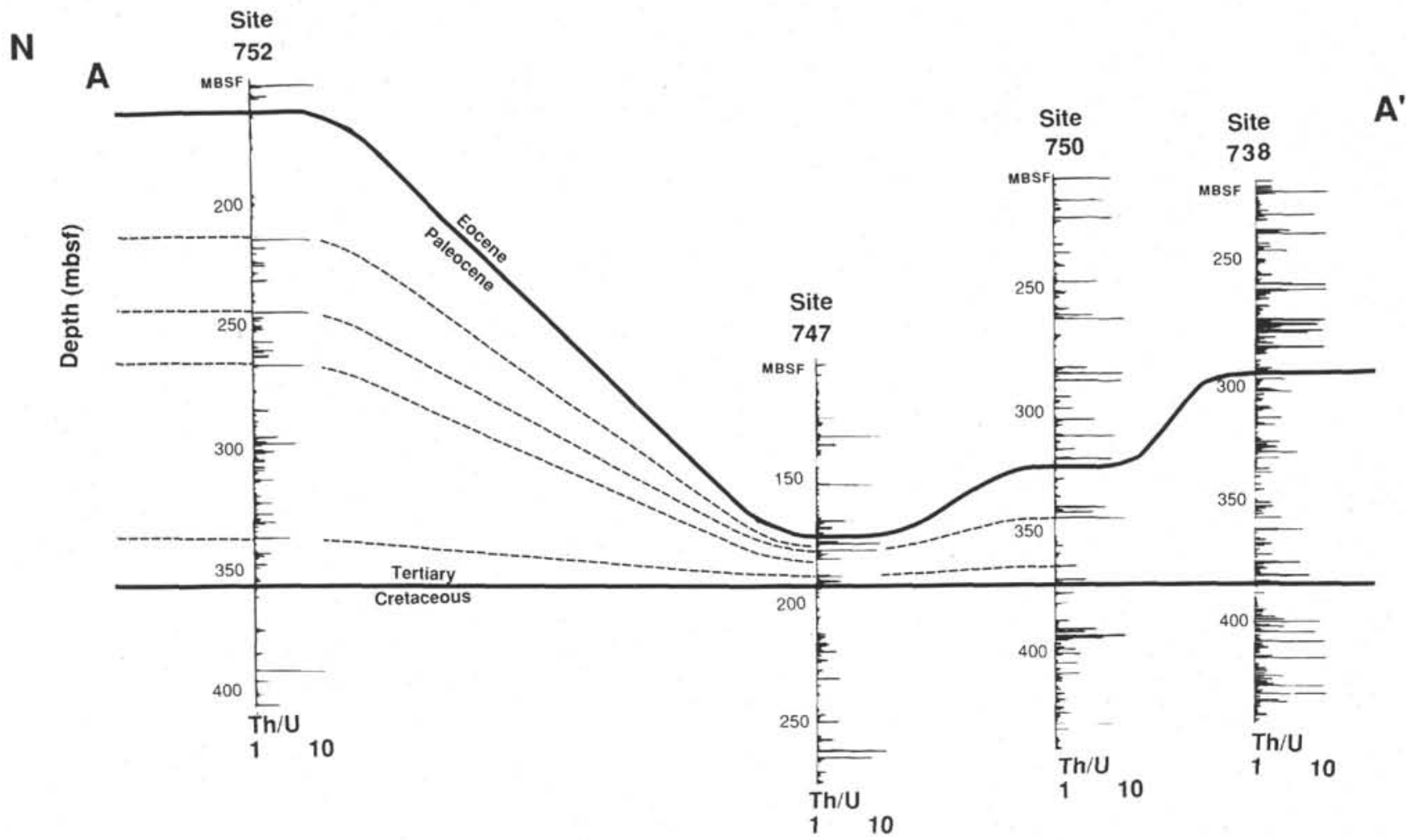

Figure 7. Correlation of $\mathrm{Th} / \mathrm{U}$ ratios across the southern Indian Ocean. Dashed lines match the strongest peaks, indicating possible ash layers representing regional events. Line of section shown in Figure 1.

\section{REGIONAL STRATIGRAPHIC CORRELATION BASED ON TH/U LOG RESPONSES}

Because the $\mathrm{Th} / \mathrm{U}$ curve is an indicator of volcanic ash layers, and because the wind-driven ash layers come from an explosive volcanic source (Bitschene et al., this volume), the $\mathrm{Th} / \mathrm{U} \log$ is useful for regional correlation. The natural gamma-ray logs from Sites 738,750 , and 752 were reprocessed using the same Alpha filtering as was used on those from Site 747. Figure 7 shows an attempt at a regional correlation of sites that have crossed the Cretaceous/Tertiary boundary. The sites formed a transect from Broken Ridge to South Kerguelen Plateau and were correlated by matching the largest $\mathrm{Th} / \mathrm{U}$ peaks. The Cretaceous/Tertiary and the Paleocene/Eocene boundaries are marked by solid lines. The Cretaceous/Tertiary boundary is used as the datum from which each well is hung. Dashed lines are used to correlate the strongest peaks, possibly representing regional events. Four possible ash layers from Site 752 may correlate with those at Site 747, and two of these may be further correlated to Site 750 . The peaks in Site 738 are not correlated to the wells further north, as the increased frequency of peaks is thought to be caused by a terrigenous source of volcanic material and not by windtransported ash layers. This work is speculative, and, again, more work is needed to confirm the presence of these ash occurrences in the rock.

\section{INFERENCES REGARDING HOTSPOT ACTIVITY}

Both the magnetic susceptibility of the core and the $\mathrm{Th} / \mathrm{U}$ ratio can be used to infer hotspot activity. It is unknown whether the hotspot delivers a constant flux of volcanic material, or whether the volcanics are produced periodically. The magnetic susceptibility and the $\mathrm{Th} / \mathrm{U}$ ratio from Site 752

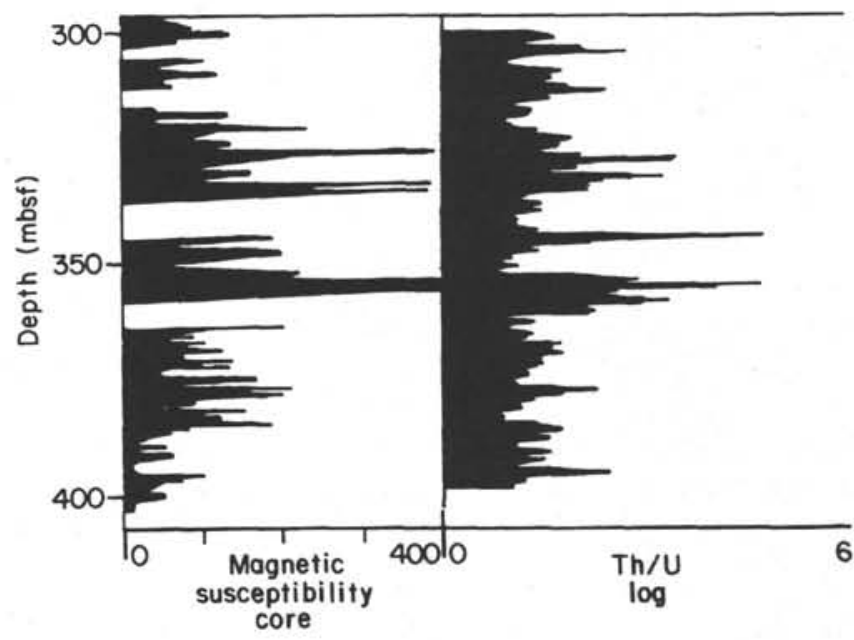

Figure 8. The cyclical nature of volcanic ash deposition in Site 752 of Leg 121 is also indicated by the magnetic susceptibility measurements made on the cores as well as the $\mathrm{Th} / \mathrm{U}$ ratio recorded on logs. Gaps in the core recovery, however, caused several ash layers to be missed completely.

are compared in Figure 8 . Both the magnetic susceptibility and the $\mathrm{Th} / \mathrm{U}$ ratio are irregular, indicating that volcanic activity was not constant. Figure 8 demonstrates the problem associated with using core-based magnetic susceptibility measurements to determine ash layers: the gaps in the core cause a number of the ash layers to be missed.

Using the sedimentation rates, we are able to estimate the cyclicity of the hotspot activity. South of Kerguelen the cyclicity 

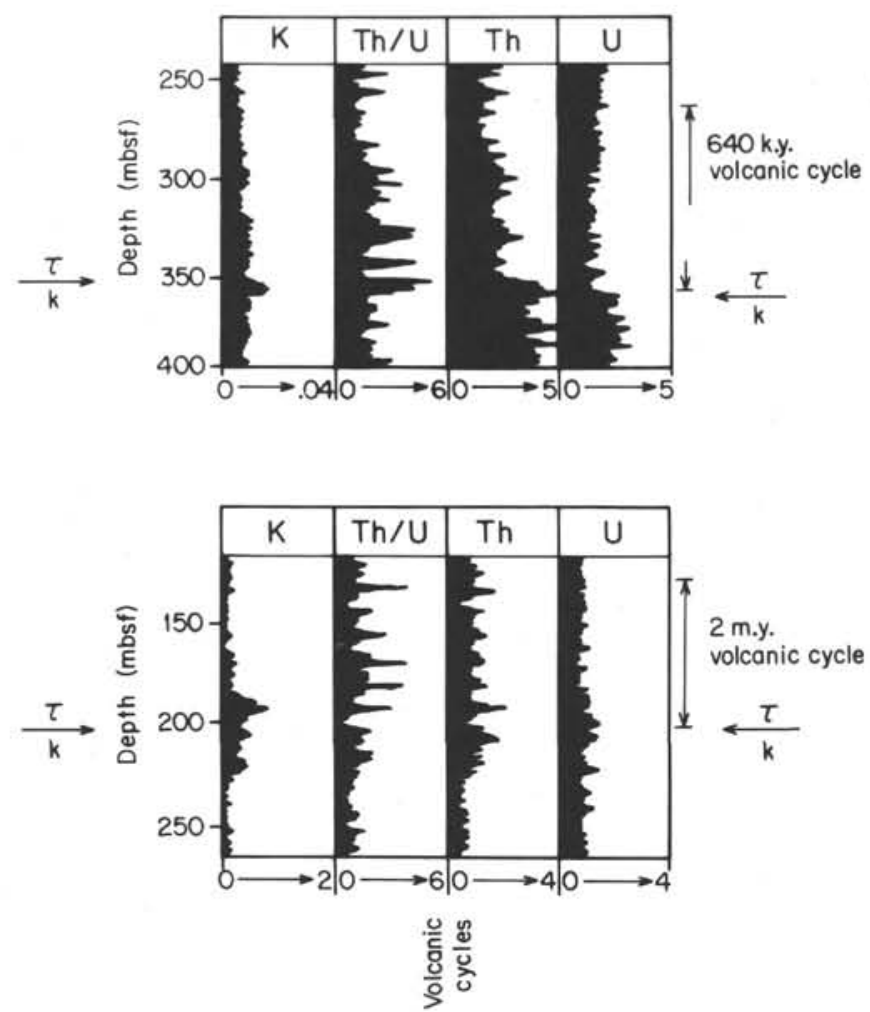

Figure 9. Variations with depth of $\mathrm{K}, \mathrm{Th}, \mathrm{U}$, and $\mathrm{Th} / \mathrm{U}$ with depth recorded by natural gamma-ray tools in Holes $747 \mathrm{C}$ (above) and 752B (below). The volcanic ash units are distinguished by their high $\mathrm{Th} / \mathrm{U}$ ratio, as expected. Note that even though $\mathrm{K}$ is enriched near the Tertiary/Cretaceous boundary, $\mathrm{Th} / \mathrm{U}$ is not unusually high compared to other eruptive cycles. The high $\mathrm{K}$ is from the deposition of deep-sea clays when carbonate sedimentation was interrupted during the extinction event. The cyclical eruptive history of the Kerguelen hotspot appears to be independent of the Tertiary/ Cretaceous extinction event, as ash layers occur both above and below the boundary. The shorter period of eruptions at Hole 752B in relation to the longer period recorded at Hole $747 \mathrm{C}$ is thought to be due to the former placement of Hole 752B downwind from the hotspot. Only the largest eruptions deposited extensive ashes to the south, reaching Site 747 .

found in sediments deposited $70-90 \mathrm{Ma}$ has a periodicity of about every 2 m.y., whereas in Hole 752B the period between volcanic ash occurrences is shorter, about every 640 k.y. (Fig. 9). The explanation for the discrepancy between the two holes may in part come from the position of each hole relative to the direction of prevailing winds (Fig. 10). Because Hole 752B was directly downwind from the hotspot, it received ashes from most eruptions. Hole 747C, however, was south of the hotspot and thus received ashes only from the largest eruptions. Strong westerly winds were experienced by the entire Leg 120 shipboard party aboard the JOIDES Resolution while drilling the Kerguelen Plateau. Similar paleowind directions are thought to have occurred since the Oligocene (Bitschene et al., this volume).

\section{SUMMARY AND CONCLUSIONS}

The reprocessed well logs improve the accuracy and signalto-noise level of the natural gamma-ray measurements made in the field and enhance the resolution of the resistivity logs in the basement section of the hole. Reprocessed well logs have

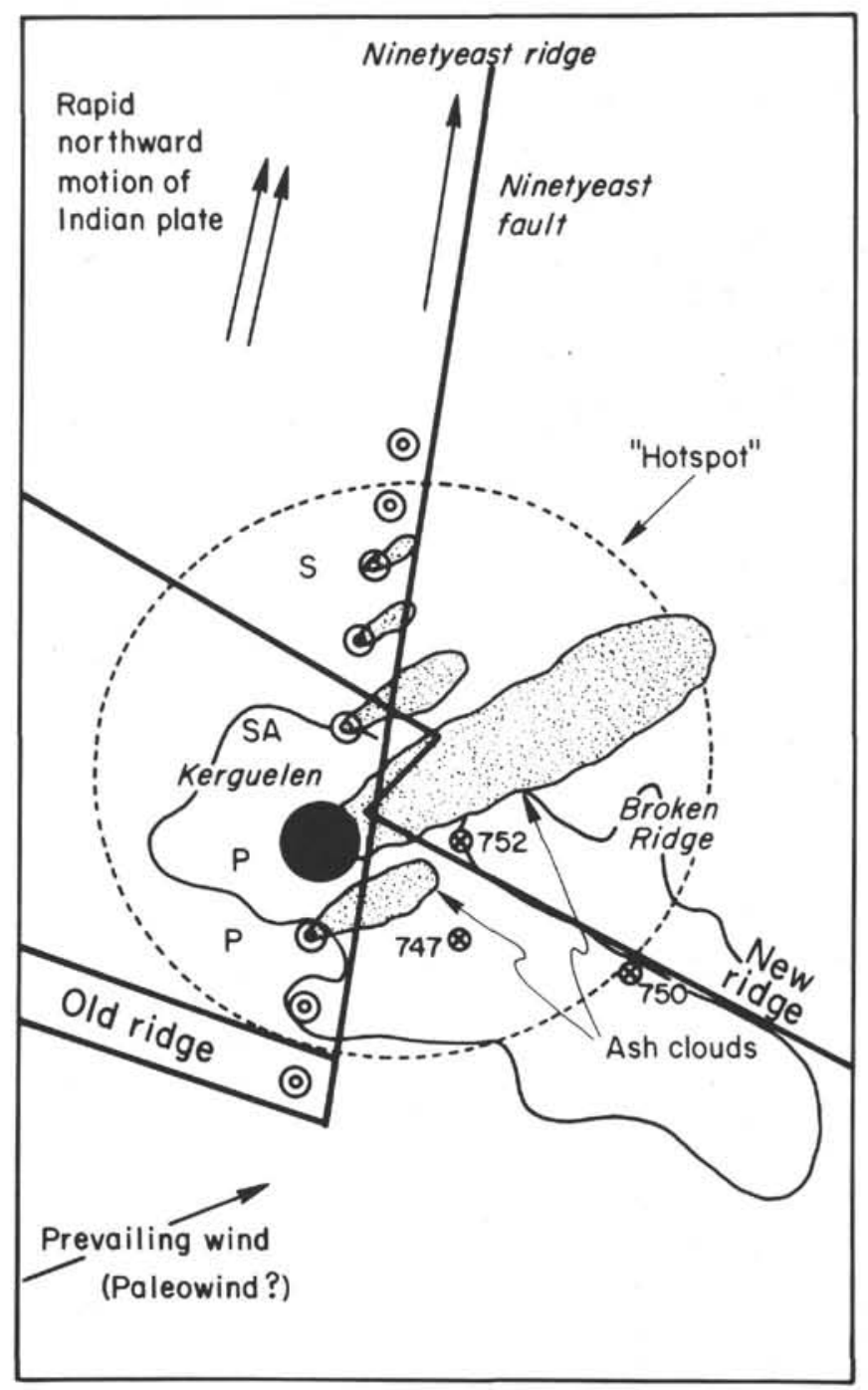

Figure 10. A reconstruction of Broken Ridge back into its place in Cretaceous time (Peirce et al., 1989) places Site 752 downwind from the likely prevailing paleowind direction at that time. Site 747 was orthogonal to the wind direction; therefore, a very large eruption of the hotspot would be required to deliver volcanic ashes to this site. The spreading directions of the old and new Southeast Indian Ridge spreading centers are also shown. The Ninetyeast Ridge is a hotspot trail away from Kerguelen.

been used to calculate the percentages of major lithologies at Site 747C. This information allows one to draw several conclusions. The percentage of carbonate lithology calculated from logs of Hole $747 \mathrm{C}$ correlates well with the percentage of $\mathrm{CaCO}_{3}$ derived from cores in the upper and lower sections of the hole. A large discrepancy exists, however, in the middle portion of the hole. A thick deposit of volcaniclastic rocks localized to Hole $747 \mathrm{C}$ exists at Site 747 . The $\mathrm{Th} / \mathrm{U} \log$ is an indicator of volcanic ash layers in the well and may be used, therefore, to correlate regional events between Site 738 of Leg 119 , Sites 747 and 750 of Leg 120, and Site 752 of Leg 121. The $\mathrm{Th} / \mathrm{U}$ curve at Hole $747 \mathrm{C}$ indicates that the volcanic activity is irregular and suggests that Site 747 was away from the prevailing wind path of the Kerguelen hotspot, whereas Site 752 was more in the direct line of the prevailing wind crossing the Kerguelen hotspot. 


\section{ACKNOWLEDGMENTS}

The logging data for Leg 120 could not have been obtained without the efforts and cooperation of the drilling superintendent and crew aboard the JOIDES Resolution. Special appreciation is expressed to Lincoln Pratson, Bob Everett, and Cristina Broglia, who edited the paper and provided very helpful suggestions.

\section{REFERENCES}

Allen, D., Barber, T., Flaum, C., Hemingway, J., Anderson, B., des Ligneris, S., Everett, B., and Morriss, C., 1988. Advances in high-resolution logging. Tech. Rev., 36:4-15.

Broglia, C., and Moos, D., 1988. In-situ structure and properties of 110 -Ma crust from geophysical logs in DSDP Hole 418A. In Salisbury, M. H., Scott, J. H., et al., Proc. ODP, Sci. Results, 102: College Station, TX (Ocean Drilling Program), 29-47.

Doveton, J. H., 1986. Log Analysis of Subsurface Geology: Concepts and Computer Methods: New York (Wiley-Interscience).

Edmunson, H., and Raymer, L. L., 1979. Radioactive logging parameters for common minerals. SPWLA, 20th Annu. Log. Symp. Trans., Paper O.
Munschy, M., and Schlich, R., 1987. Structure and evolution of the Kerguelen-Heard Plateau (Indian Ocean) deduced from seismic stratigraphy studies. Mar. Geol., 76:131-152.

Peirce, J., Weissel, J., et al., 1989. Proc. ODP, Init. Repts., 121: College Station, TX (Ocean Drilling Program).

Pezard, P. A., 1990. Electrical properties of mid-ocean ridge basalt and implications for the structure of the upper oceanic crust in Hole 504B. J. Geophys. Res., 95:9237-9264.

Schlich, R., Wise, S. W., Jr., et al., 1989. Proc. ODP, Init. Repts., 120: College Station, TX (Ocean Drilling Program).

Serra, O., 1984. Fundamentals of Well Log Interpretation (Vol. 1): The Acquisition of Logging Data: Amsterdam (Elsevier). 1986. Fundamentals of Well Log Interpretation (Vol. 2): The Interpretation of Logging Data: Amsterdam (Elsevier).

Shipboard Scientific Party, 1989. Site 747. In Schlich, R., Wise, S. W., Jr., et al., Proc. ODP, Init. Repts., 120: College Station, TX (Ocean Drilling Program), 89-156.

Date of initial receipt: 22 June 1990

Date of acceptance: 2 November 1990

Ms 120B-144 